\title{
RESILIENSI IBU DARI ANAK DENGAN DOWN SYNDROME YANG BERPRESTASI DALAM BIDANG OLAHRAGA
}

\author{
Allicia \\ Made Dharmawan Rama Adhyatma \\ anastasiallicia@gmail.com \\ made_dharmawan@ukwms.ac.id \\ Fakultas Psikologi Universitas Katolik Widya Mandala Surabaya
}

\begin{abstract}
Abstrak
Down Syndrome adalah gangguan yang disebabkan karena adanya kelainan kromosom yang berhubungan dengan retardasi mental, penampilan wajah yang khas, dan otot yang lemah. Gangguan ini menyebabkan anak yang didiagnosa memiliki gangguan ini memiliki karakteristik yang khas yaitu memiliki kemampuan intelektual, kemampuan bersosialisasi, dan kesehatan yang lebih rendah dibanding anak-anak dengan perkembangan normal lainnya. Kehadiran anak dengan gangguan Down Syndrome menyebabkan mayoritas ibu mengalami kesedihan yang mendalam, stress dan bahkan depresi. Oleh karena itu dibutuhkan kemampuan untuk dapat merespon dan menerima kehadiran anak secara positif. Resiliensi merupakan kemampuan seseorang untuk menghadapi, mengatasi, dan merespon kesulitan atau tantangan dalam kehidupan secara sehat dan produktif. Penelitian ini menggunakan metode penelitian kualitatif dengan pendekatan fenomenologi. Informan dalam penelitian ini adalah tiga ibu yang memiliki anak dengan Down Syndrome yang berprestasi dalam bidang olahraga. Informan diperoleh dengan cara menyesuaikan keadaan calon informan yang senyatanya dengan kriteria yang telah dibuat oleh peneliti. Penelitian ini menggunakan teknik analisis data inductive thematic analysis. Hasil penelitian ini menunjukkan bahwa ibu dari anak dengan Down Syndrome memiliki pola pikir yang positif dimana ia menganggap bahwa anak ini adalah pemberian yang berharga dari Tuhan, lalu mereka juga bangga atas pencapaian yang telah diraih anaknya, adanya dukungan sosial dari orang di sekitarnya yang membuatnya optimis untuk bisa mengembangkan potensi anaknya, dan mereka melakukan usaha nyata untuk mengembangkan bakat dan minat yang ada pada anaknya.
\end{abstract}

Kata kunci: Resiliensi, Ibu, Down Syndrome, Prestasi, Olahraga.

\begin{abstract}
Down Syndrome is a disorder caused by chromosome abnormalities that are associated with mental retardation, characteristic facial appearance, and poor muscle. The disorder makes a child diagnosed with this disorder has a typical characteristic such as lower intellectual capability, social capability, and healthiness than the other child with normal development. The presence of a child with Down Syndrome makes the majority of mothers experience deep sadness, stress, and depression. That's why the capability to respond and accept the presence of the child positively is needed. Resilience is an individual capability to face, deal, and respond to difficulties or challenges in life in a healthy and productive manner. This study using qualitative research method with phenomenological approach. Informant in this study were three mothers which having a child with Down Syndrome that is achieved in sport. The informant was chosen with a purposive sampling method. This study using an inductive thematic analysis data analysis technique. The results of this study indicate that mothers who
\end{abstract}


have Down Syndrome child's see her child's is a gifts, have a sense of pride in the child's achievements, social support from those around her makes her have an optimism to develop children's potential, and an effort to develop children's interests and talents.

Keywords: Resilience, Mother, Down Syndrome, Achievement, Sports

\section{Pendahuluan}

Down Syndrome adalah gangguan yang disebabkan karena adanya kelainan kromosom yang berhubungan dengan retardasi mental, penampilan wajah yang khas, dan otot yang lemah. Prevalensi anak dengan Down Syndrome sendiri adalah 1 dibanding 800-1000 angka kelahiran (Parker \& Parker, 2007). Menurut data pada tahun 2010, diperkirakan ada 8 juta penyandang Down Syndrome di dunia dan 300.000 diantaranya merupakan penyandang Down Syndrome di Indonesia (Pahlevi, 2016). Anak dengan diagnosa Down Syndrome sendiri memiliki kemampuan intelektual, kemampuan bersosialisasi, dan kesehatan yang lebih rendah dibanding anak-anak pada umumnya (Cunningham, 2006).

Seorang ibu dapat mengalami kesedihan yang mendalam ketika Kehadiran seorang anak dengan diagnosa Down Syndrome menyebabkan mayoritas ibu mengalami kesedihan yang mendalam setelah mengetahui bahwa anaknya mengalami gangguan Down Syndrome (Cunningham, 2006). Hal ini disebabkan karena ibu adalah orang yang paling pertama kali memiliki hubungan fisik dan mental dengan anak. Pernyataan ini didukung oleh Bowlby (dalam Durkin, 1995) yang menyatakan bahwa ibu adalah figur kelekatan (attachment) utama bagi anak. Ibu berperan sebagai orang pertama yang memiliki hubungan timbal balik yang bersifat emosional dan afektif dengan anak.

Reaksi yang ditunjukkan oleh ibu dari anak dengan Down Syndrome sendiri berbeda-beda. Ada yang menerima setelah mengetahui bahwa anaknya lahir dengan gangguan Down Syndrome tetapi juga ada yang melakukan penolakan. Seperti yang dilansir di LifeSiteNews.com pada tanggal 6 Februari 2015, terdapat seorang ibu yang mengalami depresi karena anaknya didiagnosa dengan gangguan Down Syndrome, sehingga ia menolak untuk menggendong anaknya setelah kelahiran. Tidak hanya itu, ia juga meminta suami untuk memberikan anaknya untuk diadopsi orang lain. Di Indonesia sendiri, pernah ditemukan bayi dengan Down Syndrome yang dibuang di tempat sampah (Diananto, 2011).

Terlepas dari reaksi-reaksi tersebut, ibu dari anak dengan Down Syndrome sendiri memiliki tuntutan untuk melakukan adaptasi terhadap kekurangan anaknya dalam kurun waktu yang sangat cepat, karena harus mengambil keputusan dan tindakan untuk mengurus segala kebutuhan anaknya. Hal ini didukung oleh pernyataan dari Rondal dan Perera (2006) yang menyatakan bahwa sejak awal, ibu dari anak dengan Down Syndrome harus dapat beradaptasi dengan kenyataan mengenai gangguan yang dialami anaknya dengan cepat dan harus dapat melakukan pengaturan terhadap lingkungan keluarganya untuk dapat membantu kebutuhan-kebutuhan khusus yang dimiliki anaknya.

Tuntutan tersebut sendiri dapat dilakukan apabila tingkat kesejahteraan dari ibu tergolong baik. Ibu dengan tingkat kesejahteraan yang tinggi menunjukkan keberhasilan dalam melakukan adaptasi (McCubbin \& McCubbin, dalam Danielson, Hamell-Bissell, \& WinsteadFry, 1993). Tingkat kesejahteraan yang tinggi dan perilaku adaptasi yang baik sendiri tidak dapat dilakukan apabila ibu dari anak dengan Down Syndrome sendiri tidak dapat mengelola emosi-emosi yang ia rasakan. Hal tersebut menunjukkan dibutuhkannya kemampuan untuk dapat mengolah kesedihan atau kesusahan yang 
dialami dengan produktif atau yang disebut juga dengan resiliensi.

Resiliensi sendiri merupakan kemampuan seseorang untuk merespon kesulitan dan trauma secara sehat dan produktif (Reivich \& Shatte, 2002). Kemampuan ini penting untuk dimiliki oleh ibu yang memiliki anak berkebutuhan khusus, seperti anak dengan Down Syndrome. Hal ini disebabkan karena apabila ibu menunjukkan respon yang produktif terhadap kesedihan yang dialaminya, ia akan memandang kehadiran anaknya sebagai hal yang positif sehingga dapat menciptakan lingkungan yang positif bagi anak dan perkembangannya. Pernyataan ini didukung oleh hasil penelitian dari Van (2007) yang menunjukkan bahwa ibu yang dapat melakukan resiliensi dan adaptasi yang baik menunjukkan respon yang positif dalam merawat anak dengan gangguan Down Syndrome. Mereka menunjukkan kemampuan untuk bertahan, dan bahkan terus bergerak maju untuk menghadapi tantangan-tantangan dalam merawat anaknya.

Indikasi terjadinya resiliensi nampak pada hasil pre-eliminaryyang dilakukan peneliti dengan dua ibu dari anak dengan Down Syndrome menunjukkan upaya untuk menerima dan memandang kekurangan yang dimiliki anaknya sebagai kesempatan untuk mencari kelebihan dan membuat kesempatan-kesempatan baru untuk dapat mengembangkan potensi yang dimiliki anak. Mereka mampu keluar dari kesedihan akibat kenyataan bahwa anaknya berkebutuhan khusus, dan bahkan dapat menggunakan kekuatan yang mereka miliki untuk mencari, menggali, dan mengembangkan potensi yang dimiliki anak. Kegigihan kedua ibu dalam mendukung dan mengembangkan potensi anak dalam bidang olaharga membuahkan hasil. Mereka berhasil membawa anaknya, yang merupakan penyandang gangguan Down Syndromemenjadi seseorang yang berprestasi. Seperti yang dilansir dalam www.soina.com, beberapa diantaranya berhasil meraih juara renang gaya bebas 100 meter Special Olympics Asia Pasific Games 2013 dan memperoleh medali perunggu dari pertandingan bola basket pada Special Olympics Asia Pasific Games 2013.

Prestasi tersebut diraih dengan adanyaperan dan bantuan ibu. Pernyataan ini didukung hasil penelitian dari Martin (2006) yang menunjukkan sejumlah anakanak berkebutuhan khusus yang berprestasi. Dari penelitian tersebut disebutkan bahwa keberhasilan anak-anak dalam meraih prestasi dalam aktivitas berolahraga dipengaruhi oleh peran dari ibu. Ibu memegang peran yang penting dalam menentukan aktivitas dan menyediakan segala fasilitas yang dapat membantu kesiapan anak dalam beraktivitas olahraga. Hal ini juga didukung dengan hasil penelitian dari Gutiérrez, Caus, \& Ruiz (2011) yang menyatakan, pada atlet yang berkebutuhan khusus, keterlibatan ibu memiliki pengaruh yang sangat tinggi dalam keberhasilan anak mereka dalam berolahraga.

Hasil penelitian Martin (2006) dan hasil wawancara pre-eliminary yang dijelaskan di atas sedikit banyaknya telah mencerminkan bahwa ibu dari anak dengan Down Syndrome yang bisa meraih prestasi tersebut telah berhasil bangkit dari kesedihan dan kesulitan yang dialami karena kehadiran anaknya yang berkebutuhan khusus dan bahkan dapat menggunakan kekuatannya untuk membantu anaknya menorehkan prestasi.

Jika dibandingkan dengan penelitianpenelitian sebelumnya yang terkait dengan resiliensi seorang ibu yang memiliki anak Down Syndrome, maka penelitian ini akan lebih berfokus pada bagaimana gambaran resiliensi ibu yang khas dalam proses pengembangan bakat dan minat anak sehingga nantinya anak akan dapat mengoptimalkan potensinya tersebut di kehidupan sehari-hari, khususnya di bidang olahraga. Selain itu, penelitian ini juga akan melihat bagaimana faktor protektif dan resiko yang muncul selama proses 
terbentuknya kondisi resilien yang dialami oleh ibu dalam memberikan perlakuan dan pengasuhan kepada anaknya di kehidupan sehari-hari.

\section{Kajian literatur}

Down Syndrome adalah gangguan yang disebabkan karena adanya kelainan kromosom yang berhubungan dengan retardasi mental, penampilan wajah yang khas, dan otot yang lemah (Parker \& Parker, 2007). Gangguan ini disebabkan karena adanya kelebihan pada kromosom 21. Adanya kelebihan pada kromosom 21 tersebut menyebabkan anak yang mengalami gangguan ini memiliki karakteristik yang khas yaitu karakteristik fisik yang khas (muka, tangan, kaki, sendi yang longgar, otot yang lemah), perkembangan yang lambat, keterbelakangan intelektual, dan permasalahan kesehatan seperti kelainan hati (Cunningham, 2006). Karakteristik yang dimiliki pada anak dengan Down Syndrome ini menyebabkan mereka selalu membutuhkan pendampingan dan perawatan yang khusus dari ibu. Hal ini didukung oleh pernyataan dari Cunningham (2006) yang menyebutkan bahwa kebanyakan anak dengan Down Syndrome tidak dapat melakukan keterampilan kehidupan dan mencapai kemandirian total. Selain itu, anak dengan Down Syndrome memiliki pola perkembangan yang lebih lambat dibanding dengan anak pada umumnya. Kekurangan-kekurangan yang ada di dalam dirinya menyebabkan mereka selalu membutuhkan pendampingan dan perawatan dari ibu. Hal ini didukung oleh pernyataan dari Cunningham (2006) yang menyebutkan bahwa kebanyakan anak dengan Down Syndrome tidak dapat melakukan keterampilan kehidupan dan mencapai kemandirian total. Sehingga, mereka selalu membutuhkan perawatan dan pendampingan dari orang. Pernyataan ini didukung oleh hasil penelitian Carr (1995) kepada anak dengan Down Syndrome dari usia 4-21 tahun, terdapat 62 dari 65 anak yang masih membutuhkan bantuan ibu. Selain itu, 38 dari 65 anak masih membutuhkan ibu untuk membantu mereka mandi. Hal ini menunjukkan bahwa anak dengan Down Syndrome selalu membutuhkan pendampingan ibu walaupun kebutuhan itu akan berkurang seiring bertambahnya usia. Sehingga, ibu harus selalu menyiapkan diri dan waktu untuk mendampingi anaknya.

Untuk dapat memenuhi tuntutan tersebut, mayoritas ibu harus mengubah jam pekerjaan, merubah jenis pekerjaan, melepaskan pekerjaan, kehidupan pribadi, bahkan kehidupan sosialnya (Mangunsong, 2009). Karena harus melepaskan kegiatankegiatan yang biasa dilakukan secara rutin, kebanyakan ibu merasa terisolasi. Menurut Cunningham (2006), banyak ibu dari anak dengan Down Syndrome merasa terisolasi secara sosial dan emosional. Mereka merasa terisolasi secara sosial karena tidak dapat berkegiatan di luar rumah karena harus fokus untuk mengurus anak mereka. Sementara, isolasi secara emosional dirasakan oleh ibu dari anak dengan Down Syndrome karena mereka merasa tidak memiliki orang yang dapat berbagi kekhawatiran bersamanya dan tidak ada yang dapat memahami posisi mereka sebagai orang tua dari anak dengan kebutuhan khusus. Selain itu, menurut hasil penelitian Sari, Baser, \& Turan (2006), hampir seluruh ibu dari anak dengan Down Syndrome menyebutkan bahwa mereka tidak memiliki waktu untuk diri sendiri karena harus merawat anaknya. Mereka juga mengatakan bahwa ayah tidak memberikan bantuan yang besar dalam kegiatan merawat anak.

Terlepas dari reaksi-reaksi negatif karena kehadiran anak dengan Down Syndrome dalam keluarga, terdapat beberapa ibu yang merasa senang karena kehadiran anak dengan Down Syndrome dalam kehidupannya. Cunningham (2006) menyebutkan bahwa beberapa dari ibu merasakan emosi yang menyenangkan selama proses merawat anak. Mereka juga menyebutkan bahwa terlepas dari 
kekurangan yang dimiliki anaknya, anaknya memiliki sisi yang menyenangkan seperti kemampuan sosial yang baik, gampang untuk diatur, dan lucu. Hal ini juga didukung oleh Cohen, Nadel \& MadN (2002) yang menyebutkan bahwa kehadiran anak dapat menyebabkan kebahagiaan tersendiri, karena kehadiran anaknya dapat membuat ibu belajar untuk memahami dunia dan menerima kesulitan yang hadir dalam kehidupan.

Kajian literatur resiliensi dalam penelitian ini berfokus pada definisi yang diungkapkan oleh Reivich \& Shatte (2002) yaitu kemampuan seseorang untuk merespon kesulitan dan trauma secara sehat dan produktif. Orang yang memiliki kemampuan ini dapat mengubah penderitaan menjadi tantangan, kegagalan menjadi sebuah kesuksesan dan ketidakberdayaan menjadi sebuah kekuatan. Orang yang menunjukkan kemampuan resiliensi tau bahwa kegagalan bukan akhir dari segalanya sehingga mereka bisa bangkit dari kegagalan dan menggunakan pengetahuannya untuk kembali ke keadaan semula.

Menurut Reivich \& Shatte (2002), terdapat tujuh aspek dari resiliensi, yaitu emotion regulation, impulse control, optimism, causal analysis, empathy, selfefficacy, dan reaching out. Regulasi emosi adalah kemampuan untuk tetap tenang di bawah tekanan. Orang yang memiliki kemampuan resiliensi punya sekumpulan skill yang dapat membuat mereka bisa mengontrol emosi, atensi, dan perilakunya. Impulse Control adalah kemampuan untuk mengendalikan dorongan nafsu yang kurang rasional. Orang yang memiliki impulse control yang lemah akan cenderung mengikuti dorongan nafsu yang keluar sesaat dari pikirannya tanpa berpikir panjang. Orang yang memiliki kemampuan resiliensi adalah orang yang optimis. Mereka percaya bahwa segala sesuatu akan berubah menjadi lebih baik. Mereka punya harapan akan masa depan dan percaya bahwa mereka punya kontrol untuk mengubah arah hidupnya. Orang-orang yang optimis adalah orang-orang yang lebih sehat secara fisik, tidak gampang depresi, lebih produktif dalam pekerjaan, dan lebih banyak menang dalam pertandingan olahraga. Optimisme menunjukkan bahwa kita bisa menangani segala macam kesulitan yang akan datang di masa depan yang ditandai dengan adanya self-efficacy, kepercayaan terhadap kemampuan diri sendiri untuk menyelesaikan masalah dan kemampuan untuk menguasai dunianya sendiri, yang merupakan kemampuan penting lain di dalam resiliensi. Optimisme memotivasi seseorang untuk mencari solusi dan terus bekerja keras untuk mengubah keadaan yang dialami menjadi lebih baik. Causal analysis adalah istilah bagi seseorang yang dapat mengidentifikasi penyebab dari sebuah masalah dengan tepat. Apabila, seseorang tidak dapat mengetahui penyebab dari masalahnya, maka ia punya kecenderungan untuk mengulang kesalahan yang sama berulang kali. Orang yang resilien dapat mengetahui penyebab dari setiap masalah yang ia hadapi dan tidak menyalahkan orang lain untuk meningkatkan self-esteem dan membebaskan dirinya dari rasa bersalah karena kesalahan mereka sendiri. Mereka juga tidak menghabiskan waktu untuk memikirkan kejadian atau keadaan yang berada di luar kendali mereka terusmenerus. Dengan mengetahui penyebab dari suatu masalah itu, mereka fokus terhadap faktor yang bisa dikontrol, melalui perubahan secara bertahap, mereka mulai untuk mengatasi, mengarahkan, bangkit, dan keluar dari masalah. Empathy adalah kemampuan untuk dapat mengetahui apa yang dirasakan seseorang melalui gejala psikologis dan emosionalnya. Gejala psikologis sendiri dapat dilihat melalui perilaku non-verbal seseorang, seperti ekspresi wajahnya, nada suaranya, dan bahasa tubuhnya. Orang yang memiliki kemampuan ini dapat memposisikan dirinya pada sepatu orang lain sehingga mereka dapat mengetahui apa yang dirasakan orang tersebut dan kira-kira apa yang akan dilakukan orang tersebut dalam 
posisinya. Self-efficacy adalah kepercayaan bahwa kita dapat menyelesaikan masalah yang akan datang dalam hidup kita dan kepercayaan terhadap kemampuan kita untuk berhasil atau sukses. Bila seseorang punya kepercayaan terhadap kemampuannya sendiri, maka ia akan dapat melakukan segala pekerjaan yang ia akan lakukan. Sebaliknya, seseorang yang tidak percaya akan kemampuannya sendiri, akan selalu merasa ragu-ragu karena takut tidak mampu untuk melakukan sesuatu. Reaching out adalah keberanian seseorang untuk mencoba sesuatu bahkan setelah ia mengalami kegagalan. Selain itu, seseorang yang memiliki kemampuan ini dapat selalu menemukan dan memandang makna positif dari kesulitan-kesulitan yang dihadapi.

Menurut Grotberg (1995), terdapat tiga faktor dari resiliensi, yaitu I have, I am, dan I can. I have adalah dukungan yang berasal dari lingkungan atau luar individu. Dukungan ini dapat berupa dukungan dari orang tua, anggota keluarga, guru, dan teman ataupun segala sesuatu yang dapat menunjang dan membantu keberlangsungan seseorang. I am adalah kekuatan diri sendiri yang didalamnya meliputi perasaan, sikap, dan kepercayaan. I can adalah kemampuan sosial dan interpersonal individu. Kemampuan ini dapat dipelajari melalui berinteraksi dengan orang di sekitar individu. Kemampuankemampuan tersebut terdiri dari kemampuan untuk berkomunikasi, melakukan pemecahan masalah, dan mencari hubungan yang terpercaya.

\section{Metode Penelitian}

Penelitian ini menggunakan pendekatan kualitatif. Penelitian kualitatif sendiri adalah pendekatan untuk mengeksplorasi dan memahami makna individu atau kelompok terhadap sebuah masalah sosial atau masalah manusia (Cresswell, 2014). Dengan menggunakan pendekatan ini, peneliti dapat memperoleh data-data berupa gambaran bagaimana persepsi dan makna dari informan mengenai masalah yang dihadapi. Tipe penelitian kualitatif yang digunakan dalam penelitian ini adalah studi kualitatif fenomenologi. Tipe penelitian ini dapat membantu peneliti untuk dapat mendeskripsikan pengalaman hidup seseorang mengenai sebuah fenomena yang terjadi (Creswell, 2014).

Dalam menentukan calon informan, peneliti menggunakan pendekatan pemilihan berdasarkan tujuan utama dari penelitian ini, yaitu seorang ibu yang telah mengalami proses resiliensi (berdasarkan kegiatan pre-eliminary dengan mengacu pada aspek-aspek resiliensi dari Reivich \& Shatte, 2002), memiliki anak Down Syndrome yang berprestasi di bidang olahraga minimal taraf nasional, dan informan merupakan ibu yang mengasuh anaknya sejak kelahiran agar dapat mengetahui gambaran resiliensi dari ibu anak dengan Down Syndrome secara lengkap.

Metode yang digunakan dalam mengumpulkan data dalam penelitian ini adalah wawancara. Adapun, jenis wawancara yang digunakan adalah in-depth interview dimana tipe wawancara ini memiliki kelebihan untuk mengungkap data secara mendalam dan personal (Creswell, 2014). Peneliti melakukan wawancara berdasarkan pedoman yang telah dibuat sebelum pengambilan data.

Teknik analisis yang akan digunakan peneliti adalah teknik analisis tematik. Teknik analisis tematik adalah proses analisis data yang melibatkan pemilihan informasi menjadi tema-tema. Tema adalah konsep atau gagasan yang muncul secara berurutan yang bisa dikenali dari sumber data yang dianalisis (Poerwandari, 2007). Analisis tematik induktif dilakukan peneliti dengan cara melakukan analisa terlebih dahulu terhadap hasil wawancara informan, kemudian memberikan label tema yang sesuai dengan topik penelitian terhadap hasil wawancara, lalu mengelompokkan tema-tema tersebut dalam tema umum untuk dijadikan dasar landasan dalam melakukan pembahasan terkait dengan topik penelitian. Dengan analisa tematik ini, 
peneliti dapat mencoba memahami situasi informasn apa adanya tanpa memaksa diri untuk membatasi penelitian pada upaya menerima atau menolak dugaan-dugaan.

Validitas dalam penelitian ini adalah validitas komunikatif dan validitas argumentatif. Validitas komunikatif dilakukan melalui konfirmasi kembali data dan analisisnya pada informan penelitian. Sedangkan validitas argumentatif dipenuhi dengan melihat kembali hasil dari penelitian dengan mengacu pada data hasil wawancara informan.

\section{Hasil Penelitian dan Diskusi}

Secara umum gambaran resiliensi ibu dari anak Down Syndrome yang berprestasi di bidang olahraga yang diperoleh dalam penelitian ini dapat disimpulkan menjadi lima tema, yaitu memandang anak sebagai anugerah, adanya rasa bangga pada prestasi anak, adanya dukungan sosial dari orang di sekitarnya, rasa optimisme untuk mengembangkan potensi anak, serta adanya upaya untuk mengembangkan minat dan bakat anak. Pada proses pertama kali mengetahui anak lahir dengan diagnosa gangguan Down Syndrome, ketiga informan menunjukkan reaksi yang negatif seperti kesedihan, kekecewaan, dan kekhawatiran. Ketiga informan menunjukkan kesedihan dan kekecewaannya karena mereka tidak pernah membayangkan akan melahirkan anak yang berbeda dengan anak-anak yang lainnya. Selain itu, mereka juga menunjukkan kekhawatiran karena mereka tidak mengetahui apa yang dimaksud dengan gangguan Down Syndrome. Pernyataan ini didukung oleh Sahin \& Gungor (2008) yang menyatakan bahwa kekhawatiran dan kecemasan akan timbul dan meningkat karena kurangnya pemahaman terhadap hasil diagnosis dan konsekuensinya. Hal ini menyebabkan pemahaman mereka tentang anak dan gangguan pada anak tergolong sedikit.

Gangguan Down Syndrome sendiri membuat anak ketiga informan memiliki karakteristik yang sama yaitu adanya keterlambatan pada perkembangan khususnya pada kemampuan berbicara dan berjalan. Hal ini didukung oleh hasil penelitian Ferreira \& Lamonica (2015) yang menyatakan bahwa anak dengan Down Syndrome menunjukkan keterlambatan dan memiliki kemampuan yang rendah dalam berbicara bila dibandingkan dengan anak-anak dengan perkembangan yang normal. Selain itu, Malak et al (2015) juga menyatakan bahwa anak dengan Down Syndrome mengalami keterlambatan dalam perkembangan motorik,khususnya dalam kemampuan berjalan dan berdiri. Ketiga anak informan belum dapat berbicara dan berjalan pada usia dimana mereka seharusnya sudah dapat menunjukkan kemampuan tersebut. Hal ini menyebabkan ketiga informan mengalami kesulitan dan kekhawatiran. Keterlambatan dalam berbicara khususnya menyebabkan informan $\mathrm{R}$ mengalami kesulitan karena tidak dapat memahami apa yang dimaksud dan diinginkan oleh anak sehingga seringkali baik informan maupun anak merasa jengkel.

Selain keterlambatan perkembangan, ketiga anak informan juga menunjukkan masalah dalam berperilaku. Dimana, menurut hasil penelitian Roizen \& Patterson (2003) ditemukan bahwa anak dengan Down Syndrome mempunyai kecenderungan untuk menunjukkan masalah pada emosi dan perilakunya. Anak informan A memiliki perilaku yang rewel dan suka menangis. Sedangkan anak informan $\mathrm{H}$ susah diatur dan mempunyai perilaku marah yang meledak-ledak. Informan $\mathrm{R}$ juga menyatakan bahwa anaknya menunjukkan perilaku hiperaktif dan cepat bosan. Hal ini didukung oleh hasil penelitian Dykens (2007) yang menyatakan mayoritas anak dengan Down Syndrome menunjukkan masalah dalam atensi dan konsentrasi, perilaku yang keras kepala, dan perilaku yang tidak menurut. Perilaku bermasalah pada anak tersebut menyebabkan ketiga informan mengalami kesulitan, khususnya pada informan $\mathrm{R}$ yang mengaku panik dan emosi ketika anak menunjukkan perilaku hiperaktif. 
Kehadiran anak dengan Down Syndrome juga menimbulkan respon yang negatif dari orang lain. Pernyataan ini didukung oleh hasil penelitian Sari, Baser \& Turan (2006) yang menyatakan bahwa keluarga yang memiliki anak dengan Down Syndrome mayoritas akan menunjukkan pengalaman mereka mendapatkan reaksi yang negatif dari orang disekitarnya. Hal ini juga pernah dirasakan ketiga informan. Anak informan A dan $\mathrm{R}$ pernah mendapatkan perlakuan yang tidak baik selama menempuh pendidikan di Sekolah. Hal ini menyebabkan anak kedua informan tersebut mogok sekolah sehingga informan A berusaha untuk memindahkan anaknya ke sekolah yang lain, sementara informan $\mathrm{R}$ berusaha untuk mendapatkan pertanggungjawaban pada pihak sekolah dan memberi peringatan kepada pihak yang memberi perlakuan yang tidak baik kepada anaknya. Selain itu, informan A dan R sendiri pernah mendapatkan komentar yang negatif dari orang lain mengenai anaknya. Hal ini membuat informan merasa jengkel dan berusaha untuk menghindari komentar negatif tersebut. Pernyataan ini didukung oleh Sari, Baser \& Turan (2006) yang menyatakan bahwa salah satu faktor yang mempengaruhi kehidupan sosial keluarga anak dengan Down Syndrome adalah reaksi negatif dari orang disekitar. Hal ini akan membuat mereka berusaha untuk menghindar agar reaksi negatif tersebut tidak mempengaruhi mereka.

Terlepas dari respon negatifnya terhadap keterlambatan perkembangan dan perilaku negatif anak, ketiga informan menunjukkan upayanya untuk menciptakan pola pikir yang positif terhadap kehadiran anak. Mereka berusaha untuk menerima kehadiran anaknya sebagai hal yang positif yakni dengan memandang kehadiran anaknya tidak sebagai beban, namun sebagai sebuah anugerah. Ketiga informan menyebutkan bahwa mereka adalah orang yang terpilih karena telah dititipkan anakanaknya. Hal ini disebutkan oleh Sari, Baser \& Turan (2006) sebagai salah satu aspek yang positif dari memiliki anak dengan Down Syndrome, dimana orang tua merasa bersyukur terhadap kehadiran anaknya dan menganggap anaknya sebagai hal yang positif. Selain itu Nunes \& Dupas (2011) juga menambahkan bahwa aspek positif tersebut dapat membuat ibu dengan anak Down Syndrome merasa penuh dan dapat memiliki kekuatan untuk berjalan ke depan.

Selain menumbuhkan pola pikir yang positif, ketiga informan juga mendapatkan banyak dukungan dari orang di sekitarnya. Dukungan sendiri dapat menumbuhkan harapan, mengurangi rasa kesepian, mengurangi stress dan dapat menimbulkan dampak positif terhadap kualitas hidup (Bishop et al, 2007). Adapun, dukungan tersebut datang dari pihak keluarga, pembantu rumah tangga, dan sekolah. Keluarga menunjukkan rasa kasih sayang terhadap anak dan membantu informan dalam merawat anak, begitu juga dengan pembantu. Hal ini membuat informan A dan $\mathrm{H}$ bersyukur karena ada yang membantu mereka untuk merawat anak selagi mereka bekerja. Selain itu, pada informan R, keluarga menunjukkan bantuannya untuk melatih anak berjalan untuk meningkatkan keterampilan berjalan anak. Selain itu, pihak sekolah menunjukkan dukungannya dengan membantu menggali potensi yang dimiliki anak sehingga informan dan anak informan mengenali minat anak dalam bidang olahraga. Tidak berhenti disitu, pihak sekolah juga memberi dukungannya dengan melatih dan mengajak anak untuk mengikuti pertandingan dalam bidang olahraga hingga anak dari ketiga informan tersebut dapat menorehkan prestasi.

Prestasi yang diraih anak dalam pertandingan olahraga tersebut menimbulkan emosi positif seperti senang dan bangga pada ketiga informan. Pernyataan ini didukung oleh Skotko, Levine, \& Goldstein (2011) yang menyatakan bahwa mayoritas dari ibu menunjukkan rasa sayang dan bangga terhadap prestasi yang diraih anak. Ketiga informan memberikan penilaian positif terhadap prestasi anak. Mereka merasa 
senang dan bersyukur karena anak mereka dapat menorehkan prestasi dalam berbagai lomba yang diikuti. Selain memberikan penilaian positif terhadap prestasi anak, informan juga menunjukkan penilaian positif terhadap aspek kognitif, keterampilan berbicara, dan karakteristik anak. Ketiga informan menilai anak mereka memiliki peningkatan dalam aspek kognitif sehingga mereka menyatakan bahwa anak mereka sudah semakin pintar. Selain itu, ketiga informan juga memberi nilai yang positif terhadap keterampilan berbicara pada anak mereka. Hal ini ditunjukkan dengan menyatakan bahwa semakin banyak orang yang mengetahui apa yang dimaksud anak ketika berbicara. Selain itu, ketiga informan juga menunjukkan penilaian yang positif terhadap karakteristik anak mereka yang ditunjukkan pada aspek kemandirian. Ketiga informan menilai anak sebagai anak yang mandiri, sehingga mereka tidak mengalami kesulitan dalam merawat anak mereka. Hal ini didukung hasil penelitian yang menemukan bahwa ibu akan menunjukkan kebahagiaan mereka atas peningkatan yang ditunjukkan oleh anak mereka sekecil apapun peningkatannya sebagai hasil dari usaha dan dedikasi mereka (Nunes \& Dupas, 2011)

Penilaian positif, pola pikir yang positif, dan dukungan yang diterima membuat informan dapat menerima kehadiran anaknya. Hal ini ditunjukkan dengan bagaimana informan yang awalnya menunjukkan reaksi yang negatif terhadap kehadiran anak, mulai menerima kehadiran anaknya dan mengesampingkan emosinya untuk melakukan upaya bagi kebaikan anak. Pernyataan ini didukung oleh Lam \& Mackenzie (2002) yang menyatakan ketika ibu mulai menerima anaknya, sikap dan perilakunya terhadap anak juga akan berubah. Hal ini ditunjukkan dengan bagaimana informan A dan $\mathrm{H}$ yang awalnya merasa sedih dan khawatir karena kehadiran anaknya, memutuskan untuk menerima keadaan anak dan berfokus pada perkembangan anak. Selain itu, informan A dan R yang awalnya memiliki kekhawatiran dan ketakutan untuk memiliki anak lagi karena takut gangguan yang ada pada anaknya yang pertama dapat menurun ke anak yang kedua, mulai mengumpulkan keberanian dan memutuskan untuk memiliki anak lagi agar anaknya yang pertama tidak sendirian.

Selain itu, ketiga informan juga menunjukkan rasa optimis dengan menyatakan bahwa anak mereka akan berkembang menjadi lebih baik. Keyakinan ini membawa informan untuk melakukan berbagai upaya bagi anak seperti upaya untuk mengatasi hambatan dalam perkembangan anak, meningkatkan perkembangan anak, dan upaya untuk mengembangkan minat bakat anak. Pernyataan ini didukung dari hasil penelitian Greenberg et al (2004) yang menyatakan bahwa optimisme adalah sebuah sumber yang memberi dampak yang menguntungkan bagi ibu yang memiliki tanggung jawab dalam merawat anak dengan Down Syndrome, dimana optimisme akan membuka kesempatan bagi ibu untuk memulai upaya baru untuk merawat anak mereka.

Anak dengan Down Syndrome menunjukkan keterlambatan dalam perkembangan mereka, khususnya pada keterampilan berjalan dan berbicara. Hal ini juga nampak pada ketiga anak informan, sehingga ketiga informan menunjukkan berbagai upaya seperti membawa anak untuk mengikuti speech therapy untuk meningkatkan keterampilan berbicara pada anak. Selain itu, informan A dan $\mathrm{R}$ juga melatih anak berjalan di rumah untuk meningkatkan meningkatkan keterampilan berjalan anak. Hal ini didukung oleh Nunes \& Dupas (2011) yang menyatakan bahwa keterampilan kognitif dan motorik anak dengan Down Syndrome dapat berkembang pesat jika mendapatkan pelatihan dan menjadi bagian dari kehidupan sehari-hari anak.

Ketiga informan juga menunjukkan upayanya untuk mengembangkan minat bakat pada anak yang ditunjukkan dalam bidang olahraga. Hal ini mereka lakukan 
dengan mendukung anak dalam setiap kegiatan olahraga. Pernyataan ini didukung oleh Tamar, Kelly \& James (2003) yang menyatakan bahwa dukungan dan dorongan dari orang tua dan teman dapat meningkatkan motivasi anak dengan Down Syndrome dalam aktivitas berolahraga. Adapun, upaya ketiga informan untuk mendukung anak dalam kegiatan berolahraga ditunjukkan dengan menyediakan fasilitas bagi anak untuk latihan berolahraga, membantu menyiapkan persiapan lomba, dan memberikan dukungan pada saat anak mengikuti pertandingan olahraga.

Informan A menyediakan sebuah ring basket di rumahnya untuk mengenalkan anak pada olahraga basket dan memfasilitasi anak agar bisa berolahraga di rumah. Selain itu, kedua informan yang lain juga ikut mendampingi anak ketika latihan. Hal ini khususnya diperhatikan oleh informan $\mathrm{R}$ untuk menghindari perilaku mogok anak dalam latihan, sehingga ia selalu mendukung dan mendampingi anaknya. Hal ini didukung oleh Shields \& Barr (2011) yang menyatakan bahwa dukungan dan didikan orang tua dapat mendorong partisipasi anak dalam aktivitas olahraga. Sebelum mengikuti lomba sendiri, ketiga informan juga ikut mempersiapkan persyaratan lomba. Bahkan, informan $\mathrm{R}$ berusaha untuk menjaga mood anaknya sebelum anak mengikuti pertandingan. Ketika anak ikut dalam suatu pertandingan, ketiga informan juga ikut mendampingi dan mendukung sehingga anak dapat menorehkan prestasinya dalam berbagai lomba dalam bidang olahraga yang diikuti.

\section{Simpulan}

Kehadiran anak dengan diagnosa gangguan Down Syndrome merupakan hal yang tidak mudah bagi seorang ibu sehingga mereka cenderung menunjukkan reaksi yang negatif seperti kesedihan, kekecewaan, maupun kekhawatiran. Reaksi ini muncul karena anaknya lahir tidak seperti anak dengan perkembangan yang normal lainnya. Kehadiran anak dengan Down Syndrome sendiri ditandai dengan karakteristik yang khas. Adapun, karakteristik tersebut adalah keterlambatan dalam perkembangan dan perilaku yang bermasalah. Selain itu, kehadiran anak dengan Down Syndrome juga menuai respon yang negatif dari orang disekitar.

Terlepas dari kesulitan yang dialami, ibu menunjukkan faktor protektif yang membantunya untuk menerima kehadiran anak. Salah satu faktor protektif tersebut adalah dukungan dari berbagai pihak. Dukungan tersebut diberikan dalam bentuk merawat, melatih, maupun pemberian kasih sayang. Selain itu, informan juga menumbuhkan pola pikir dan penilaian positif terhadap kehadiran dan perkembangan anak. Ketiga hal ini membuat informan mulai menunjukkan penerimaan pada anak. Informan mulai menunjukkan upaya untuk memahami anak dan menumbuhkan optimismenya terhadap anak. Sebagai bentuk dari penerimaan, informan juga menunjukkan berbagai upaya untuk meningkatkan perkembangan anak dan mengembangkan minat bakat anak dalam bidang olahraga.

Upaya-upaya yang dilakukan informan dalam mengembangkan minat bakat anak dalam bidang olahraga adalah mendampingi dan memfasilitasi anak dalam kegiatan olahraga, membantu menjaga kesehatan fisik dan mental anak, mempersiapkan persyaratan lomba, dan mendukung anak dalam ajang lomba. Upaya-upaya ini pun berhasil membawa anak-anak mereka meraih berbagai prestasi pada bidang olahraga dalam kancah nasional maupun internasional.

\section{Daftar Pustaka}

Bishop SL, Richler J, Cain AC, Lord C. (2006). Predictors of perceived negative impact in mothers of children with autism spectrum disorder. American Journal on Mental Retardation, 112:450-461. 
Carr, J. H. (1995). Down Syndrome: Children Growing Up. New York: Cambridge University.

Cohen, W. I., Nadel, L., \& MadN, M. E. (2002). Down Syndrome: Visions for the 21st Century. New York: WileyLiss, Inc.

Creswell, J. W. (2014). Research design: qualitative, quantitative, and mixed methods approaches (4th edition). USA: SAGE Publications, Inc.

Cunningham, C. (2006). Down Syndrome An Introduction for Parents and Carers. London: Souvenir Press.

Danielson, C. B., Hamell-Bissell, D., \& Winstead-Fry. P. (1993). Families, health \& illness: Perspectives on coping and intervention. St. Louis: Mosby.

Diananto, W. (2011). Soraya Haque, Terkenang Bayi Down Syndrome yang Dibuang ke Tempat Sampah. [Artikel Online] diakses pada 21 Maret 2019 dari https://archive.tabloidbintang.com/ga ya-hidup/kesehatan/10709-sorayahaque-terkenang-bayi-downsyndrome-yang-dibuang-ke-tempatsampah.html

Dykens, E.M. (2007). Psychiatric and behavioral disorders in persons with Down Syndrome. Ment Retard Dev Disabil Res Rev 13, 272-278.

Durkin, K. (1995). Developmental social psychology: From infancy to old age. Oxford, UK: Blackwell Publishers Ltd.

Ferreira-Vasques, A. T., \& Lamonica, D. A. C. (2015). Motor, linguistic, personal and social aspects of children with Down Syndrome. Journal of Applied Oral Science, 23(4), 424-430. doi:10.1590/1678-775720150102.

Greenberg, J. S., Seltzer, M. M., Krauss, M. W., Chou, R. J.-A., \& Hong, J. (2004). The Effect of Quality of the Relationship Between Mothers and Adult Children With Schizophrenia, Autism, or Down Syndrome on Maternal Well-Being: The Mediating
Role of Optimism. American Journal of Orthopsychiatry, 74(1), 14-25.

Grotberg, E. (1995). A Guide to Promoting Resilience in Children: Strengthening the Human Spirit. Netherland: Bernard Van Leer Foundation.

Gutiérrez, M., Caus, N., \& Ruiz, L. M. (2011). The influence of parents on achievement orientation and motivation for sport of adolescent athletes with and without disabilities. Journal of Leisure Research, 43, 355-382.

Johnson, Ben. (2015, Februari 6). Wife tells husband to choose between giving up baby with Down Syndrome, or divorce: he chose the baby. Diakses dari https://www.lifesitenews.com/ news/father-chooses-son-with-downsyndrome-over-his-wifes-divorceultimatum.

Lam, L. \& Mackenzie, A. E. (2002). Coping with a child with down syndrome: The experiences of mother in Hong Kong. Qualitative Health Research, 12 (2): 223-237.

Malak, R., Kostiukow, A., KrawczykWasielewska, A., Mojs, E., \& Samborski, W. (2015). Delays in Motor Development in Children with Down Syndrome. Medical Science Monitor, 21, 1904-1910. doi: $10.12659 / \mathrm{msm} .893377$

Mangunsong, F. (2009). Psikologi dan Pendidikan Anak Berkebutuhan Khusus. Depok: Lembaga Pengembngan Sarana Pengukuran dan Pendidikan Psikologi (LPSP3).

Martin, J. J. (2006). Psychological aspects of youth disability sport. Adapted Physical Activity Quarterly, 23, 6577.

Nunes, M. D. R., \& Dupas, G. (2011). Independence of children with Down Syndrome: The experiences of families. Revista Latino-Americana de Enfermagem, 19(4), 985-993. http://dx.doi.org/10.1590/S010411692011000400018. 
Pahlevi, R. (2016). "Down Syndrome" Bukan Akhir Dunia. [Artikel Online] diakses pada 21 Maret 2019 dari http://edukasi.kompas.com/read/201 6/02/26/17030051/.Down.Syndrome. Bukan.Akhir.Dunia.

Parker, J. N \& Parker, P. M. (2007). Down Syndrome: A Bibliography And Dictionary for Physicians, Patients, and Genome Researchers. USA: ICON Group International.

Poerwandari, E.K. (2007). Pendekatan Kualitatif untuk Penelitian Perilaku Manusia. Jakarta: LPSP3 Fakultas Psikologi Universitas Indonesia.

Prestasi Internasional. Diambil pada tanggal 18 April 2019 dari http://www.soina.id/pages/prestasi/id /prestasi/60.

Reivich, K. \& Shatte, A. (2002). The resilience factor: 7 Essential skills for overcoming life's inevitable obstacles. USA: Three Rivers Press

Roizen N. J, \& Patterson, D. (2003). Downs syndrome. Lancet, 361: 1281-1289.

Rondal, A. J., \& Perera, J. (2006). Down Syndrome: Neurobehavioural Specificity. Chicester: Wiley.

Sahin, N. H., \& Gungor, I. (2008). Congenital anomalies: Parent's anxiety and women's concerns before perinatal testing and women's opinions towards the risk factors. Journal of Clinical Nursing, 17(6), 827-836.

Sari, H.,Y, Baser, G., Turan, J.,M. (2006). Experiences of mothers of children with Down Syndrome. Paediatr Nur, 18(4):29-32

Shields, N \& Barr, M. (2011). Identifying the barriers and facilitators to participation in physical activity for children with Down Syndrome. Journal of Intellectual Disability Research, 55 (2), 1020-1033.

Skotko, B.G., Levine, S.P., \& Goldstein, R. (2011). Having a son or daughter with Down Syndrome: Perspectives from mothers and fathers. Am JMed Genet Part A 155, 2335-2347.

Tamar, H., Kelly, H., \& James, R. (2003). Barriers and Supports for Exercise Participation Among Adults with Down Syndrome, Journal of Gerontological Social Work, 38:1-2, 161-178, DOI: 10.1300/J083v38n01_03.

Van, Riper M. (2007). Families of Children with Down Syndrome: Responding to "A Change in Plans" with Resilience. Journal of Pedriatic Nursing, 22 (2), 124-125. 